\begin{abstract}
Iranica
Abstracta Iranica Revue bibliographique pour le domaine irano-aryen

Volume 30 | 2010

Comptes rendus des publications de 2007

\section{Les mondes chiites et l'Iran. Paris - Beyrouth, Karthala - IFPO, 2007, 484 p.}

\title{
Pierre Lory
}

\section{(2) OpenEdition}

9 Journals

\section{Édition électronique}

URL : http://journals.openedition.org/abstractairanica/37912

DOI : 10.4000/abstractairanica.37912

ISSN : 1961-960X

Éditeur :

CNRS (UMR 7528 Mondes iraniens et indiens), Éditions de l'IFRI

\section{Édition imprimée}

Date de publication : 8 avril 2010

ISSN : 0240-8910

\section{Référence électronique}

Pierre Lory, «Les mondes chiites et I'Iran. Paris - Beyrouth, Karthala - IFPO, 2007, 484 p. », Abstracta Iranica [En ligne], Volume 30 | 2010, document 220, mis en ligne le 08 avril 2010, consulté le 26 septembre 2020. URL : http://journals.openedition.org/abstractairanica/37912 ; DOI : https://doi.org/ 10.4000/abstractairanica.37912

Ce document a été généré automatiquement le 26 septembre 2020.

Tous droits réservés 
Les mondes chiites et l'Iran. Paris Beyrouth, Karthala - IFPO, 2007, 484 p.

Pierre Lory 
1 Cet ouvrage est né de l'initiative de chercheurs - notamment du CNRS - travaillant sur les questions politiques et sociales du Proche-Orient. Il entend fournir un panorama réfléchi des mondes chiites dans leur état le plus récent (après l'invasion de l'Irak), en fournissant les clés explicatives remontant à des enjeux plus anciens. Des exposés d'ensemble (S. Mervin, O. Roy) introduisent le volume.

2 Une partie de la problématique en est territoriale. On trouvera des chapitres originaux sur les courants actuels dans les communautés chiites du Golfe (L. Louër), de l'Afghanistan (A. Monsutti), en Turquie (Th. Zarcone, qui distingue soigneusement les chiites des Alévis) et en Azerbaïdjan (B. Balci), en Ouzbékistan (B. Pétric) et au Sénégal (M. A. Leichtman). Des analyses très substantielles sont bien sûr réservées au Hezbollah libanais (J.Alagha, K. Chaib) et aux courants irakiens, notamment sous sa forme sadriste (P.-J. Luizard, P. Harling, H. Y. Nasser).

Une autre partie fournit d'importants éléments sur les débats intellectuels, doctrinaux, qui traversent les mondes chiites. On y trouvera évoqué, dans leur interaction, l'impact des œuvres de Shariati (S. Shariati), de Soroush (M. Mottaghi), de Mohsen Kadivar ou de H. Y. Eshkevari, de M. Malekian - et de bien d'autres - comme autant d'exemples de la vitalité des débats qui animent le monde chiite, complété par des chapitres synthétiques par S. Mervin, A. Dahlén.

4 A la lecture de cet ouvrage, on comprend l'importance du pluriel dans son titre. Malgré le rôle prépondérant joué par l'Iran, il est clair que chacune des communautés chiites réagit selon des intérêts et une logique très particuliers. L'intérêt de cet ouvrage est durable. Contrairement à d'autres recueils traitant de l'actualité immédiate, celui-ci contextualise et renvoie le chiisme à ses débats de fond; il restera certainement une référence pour les lecteurs avides de comprendre, comme pour les chercheurs de profession, pour de longues années.

\section{INDEX}

Thèmes : 7. Islam

\section{AUTEURS}

PIERRE LORY

IFPO, Damas 